\title{
INSCRIBING MATERNALISM IN THE SOCIAL INVESTMENT PERSPECTIVE
}

\author{
Jane Jenson \\ Université de Montréal
}

\begin{abstract}
Beginning in the 1960s, second-wave feminists framed their claims against the discourses and policy practices in the male breadwinner model that was widespread at the time. They found it too maternalist, accepting the traditional role of women as mothers responsible for care. It is, therefore, ironic that the male breadwinner model is no longer promoted by public policy communities, and yet, maternalism has returned to policy practices. The social investment perspective, now dominant in European social policy, addresses women primarily as mothers and secondarily as workers. This article documents this return to maternalism and attributes the shift to two ideational mechanisms present in the universe of political discourse within which proponents of the social investment perspective act. One is a mechanism of "being aware of gender," including differences generating inequalities, and the other is a mechanism of "writing out gender equality." Both drive the process of inscribing maternalism into policy and programmes.
\end{abstract}




\section{Introduction}

During the first wave of feminism in the early decades of the $20^{\text {th }}$ century, in Europe as in North America, women often fashioned their demands around the status of "mother," advocating a differentiated citizenship that recognised their contribution to the nation as different from that of men. Others, however, called for full citizenship for "women" in the name of equal rights of the two sexes, as individuals in the liberal wing or as workers in the socialist stream of feminism. ${ }^{1}$ This tension between claims made in the name of "mothers" or in the name of "women" never disappeared in subsequent decades. Nevertheless, by the second wave of feminism beginning in the 1960s, the dominant streams of feminism - whether radical, liberal, or socialist - framed their claims in the name of women, and indeed struggled against discourses and policy practices that they considered too maternalist.

Post-1945 welfare regimes incorporated and indeed reinforced the male-breadwinner model, however. Many policies across European countries, from those of social care to those of urban design and transport, assumed that families were composed of a male worker and his dependents, including his wife who was the primary carer for children, elderly parents, and the house. Women were assumed either not to be employed or, if they were, to have jobs and be working hours that would not interfere with their caring responsibilities.

Faced with such policies, second-wave feminists struggled against the widespread assumption that the mother responsible for care work in the home was the natural and desirable complement to the male breadwinner. It is therefore ironic that the male breadwinner model is no longer promoted by public policy communities, and yet maternalism has returned to policy practices, this time within a universe of discourse characterised by "gender awareness." As welfare regimes have been reformed in the last two decades, an updated and modernised version of policy-promoted maternalism has become characteristic of much contemporary social policy. ${ }^{2}$ While policy communities recognise the need to encourage, promote, and ensure high rates of female labour force participation, social policy emphasises the mother-child relationship. This is certainly the case of the increasingly popular social investment perspective, considered by leading social policy experts to be the "dominant paradigm" in Europe now (Cantillon and Van Lancker 2013, 553).

This article argues that the return to maternalism is the result of two ideational mechanisms present in the universe of political discourse within which proponents of the social investment perspective act. One is a mechanism of "being aware of gender" and the other is a mechanism of "writing out gender equality." Both drive the process of inscribing maternalism into policy and programmes.

\footnotetext{
${ }^{1}$ For an early overview of different meanings of feminism in these years, see Offen (1988). For an overview of firstwave links between feminist claims and maternalist social policy, see Koven and Michel (1990). For more recent versions of maternalism, see Mahon (2006).

${ }^{2}$ I choose to use the term maternalism rather than familialism, as Mary Daly does (2011, for example). This is because it was the gender division of labour and the assignments of roles and values to mothers rather than the institution of the family that most disturbed second-wave feminists. Second, with increased numbers of lone-parent families still overwhelmingly headed by women, as we will see in later sections, it is mothers who are often targets of policy discourse and interventions.
} 


\section{The process of inscribing maternalism. Discourse and mechanisms}

Modifications of policy ideas never "fall from the sky" any more than public policies are an automatic response to new needs created by structural changes. New ideas expressed in policy discourse and practices of policy design are the result of policy-makers' efforts to make sense of novel social and economic circumstances and challenges. In Europe over the last decades, major socio-economic changes have remade economies and societies. These include economic restructuring in response to globalisation and liberalisation, altered family structures in reaction to profound changes in social norms, and rising inequalities in income (OECD 2011). New social risks have clearly been created (Bonoli and Natali 2012).

But responses are not automatic. Understanding the policies chosen requires attention to the assemblage of ideas in the universe of political discourse and particularly the ideational mechanisms in play. To understand such mechanisms and assemblages, this article uses the concept of a universe of political discourse that emphasises the association between discursive formulations and policy practices (Jenson 1989). ${ }^{3}$ The universe of political discourse is a space in which socially-constructed meaning systems and practices jostle each other for social attention and legitimacy. It is also a terrain on which institutions engage in practices of "puzzling" about public policy directions, particularly in moments of uncertainty about the effectiveness of policy interventions and instruments. ${ }^{4}$ Third, it is the terrain upon which actors struggle for recognition and representation. The triadic configuration of political discourse, institutional puzzling, and struggles for recognition provides greater representative legitimacy to some actors and their ideas than to others and, therefore, to their policy practices (Jenson 1989, 238ff; 2012, 23-24; Hall 1993, 289).

The universe of political discourse sets discursive parameters and boundaries of debate, legitimises the participation of actors and claimants, and patterns interactions (Smith 2007, 9). By observing such effects, certain mechanisms become visible. Mechanisms are a key link to context, including the broad universe of political discourse (Ancelovici and Jenson 2013). ${ }^{5}$

The claim made here is that the two mechanisms identified (being aware of gender and writing out of gender equality) were deployed within the universe of political discourse as European policymakers at national and supranational levels engaged in puzzling about their responses to economic restructuring and social inequalities and as they gradually systematised their ideas about the social investment perspective. To support this argument the rest of the article describes the move towards the social investment perspective and the norm of the adult worker model. It then traces the contribution of the two mechanisms to this process.

\footnotetext{
${ }^{3}$ The concept has frequently been used to understand social movement strategies (for example, Smith 2007) as well as policy practices (for an overview, see Padamsee 2009).

${ }^{4}$ The notions of puzzling and powering are obviously a reference to Hugh Heclo's $(1974,305)$ argument in his seminal study of social policy learning in Britain and Sweden: "Tradition teaches that politics is about conflict and power. This is a blinkered view of politics... Politics finds its sources not only in power, but also in uncertainty... Policy making is a form of collective puzzlement on society's behalf."

${ }^{5}$ Mechanisms are distinct from variables in that they derive their effect not from changes in their value, but from their presence in combination with other mechanisms. The contemporary analytic turn to mechanisms brings a return to a focus on action (and therefore actors), and is associated with action verbs that suggest both agency and dynamism (Paquet 2014).
} 
The method is, following Mary Daly (2011, 3), not an effort to reconstruct detailed national trajectories, but rather to identify developments across a range of European countries and in the European Union. The primary objective is to identify what she calls "the lineaments of the models or sets of ideas," or what are termed here the discourse of processes and mechanisms. There are "risks involved in this kind of overview exercise. One risk is of decontextualization... [while] the fact that reform is both wide ranging and quite rapid also exposes one to the danger of an analysis that quickly becomes outdated" (ibid.). The utility as well as the appeal of this method is that "in a time of change it is very important to put down a marker about what things were like at X point in time" (ibid.). This method is not unlike that used, for similar reasons, in other recent books that map the shifting contours of social policy in Europe (for example, Morel, Palier, and Palme 2012; Bonoli and Natali 2012; Evers and Guillemard 2012; Hemerijck 2013).

\section{From the male breadwinner model to the social investment perspective}

Scholars analysing social policy are familiar with the characterisation of the European universe of political discourse after 1945 as promoting the norm of the male breadwinner. Jane Lewis (2001, 153) summarises the norm this way: "The male breadwinner model also worked at the level of prescription. Policy makers treated it as an 'ought' in terms of relationships between men and women, and in many countries it served to underpin both social policies that assumed female dependence on a male wage and family law." There is no need to review the numerous studies that document the presence of the norm and its consequences for public policy design. ${ }^{6}$ It is important, nonetheless, to look back on it to clarify some vocabulary so as to be clear about the changes being described here.

The complement to the male bread-winner that characterised much of social policy in the middle decades of the $20^{\text {th }}$ century was the stay-at-home mother. In this universe of political discourse, women made their contribution as citizens primarily through their roles as carers - for children, for men, for the elderly, for the house. Social policy provided support for women to perform those roles either directly (via, for example, mothers' allowances, or survivor benefits and social assistance when a male wage was not available) or indirectly, by fostering conditions for a high male wage or replacement for it (collective bargaining, pensions, unemployment insurance, and so on). Thus, social policy was most frequently designed to allow women - whether living in couples or as lone parents - to conform to a maternal norm. While there were always variations in access to such benefits and certainly in their generosity, there was a discursive consensus.

Social policy translated this discourse into practice via its benefit structures. This was true in the "people's home" of Sweden, the iconic example of a social democratic welfare regime (DauneRichard and Mahon 2001).

The struggle against poverty dominated Scandinavian social policy from the 1890s until the 1950s. This struggle was strictly genderized. It had as its starting point the male breadwinner model, with a working and supporting husband and a housewife, mainly responsible for housework and childcare. The construction of the social insurances presupposed this difference between men and women. The new social insurances were primarily directed towards wage earners and the labour

\footnotetext{
${ }^{6}$ For one recent overview, see Daly (2011).
} 
market, while other reforms were targeted to give support to women as mothers. (Klas and Ámark 2001, 159)

Only when women entered the labour force did the social insurance system become available to them (ibid.). In liberal regimes, the maternal role also shaped social policy; lone mothers were able to remain on social assistance with no employment obligation until the oldest child reached schoolleaving age (Lewis et al. 2008, 275). In Bismarckian regimes such as Germany and the Netherlands, the discourse of the male breadwinner was also solidly supported in political discourse and policy design (Gottschall and Bird 2003).

However, by the 1990s, it was evident in several European countries that another model was displacing the male breadwinner norm in the universe of political discourse. This is what Jane Lewis and others have termed the "adult worker model" (Lewis 2001). According to this new norm, women are no longer excused from participation in the labour force in order to care; they are expected to be able to "reconcile" work and family.

There is little dispute that social policy discourse has moved towards the norm of the adult worker model, at both the national and European level. ${ }^{7}$ The changed norm was sometimes justified as a response to second-wave feminism's claim for equality. Decades of action by women's movements and their allies spotlighted the structures of inequalities reproduced by the male breadwinner model and called for it to be replaced with employment and social policies. They also called for antidiscrimination protections that would promote women's autonomy and employment, and more equal gender relations in all spheres. From the 1960s on, feminists advocated for full social citizenship rights, such as the right to equal pay for work of equal value, individualised taxation and pension rights, affordable and quality childcare, and so on. In particular, they demanded policy design for childcare and leaves from employment that assumed both parents "parented," and social supports and services that were "parentalist" rather than maternalist (for example, Mahon 2006, 178). The universe of political discourse filled with talk of gender equality, and policy changes were forthcoming in the form of new services (e.g., childcare), rights (e.g., parental leave, equal pay), and benefits (e.g., individuation of social insurance).

The root causes of this shift in the universe of political discourse towards a new norm are numerous, from the mobilisations for equality by the second-wave women's movement to the arrival of the post-industrial economy and its service sector that absorbed so many women workers. But also important by the 1980s were neoliberalism's attack on welfare benefits and state spending and structural changes involving labour market restructuring, which rendered a single, even male, wage insufficient; changing family patterns that brought a rising number of female-headed lone-parent families; demographic shifts that threatened the fiscal foundations of social insurance policy instruments; and so on. The point here is not to document the reasons for this new norm of the adult worker model, but rather to acknowledge its existence. It is also important to identify its place in the larger change in political discourse into which it fit by the mid-1990s, that is, the elaboration of the social investment perspective on social policy.

The social investment perspective and the policies associated with it are the products of epistemic communities composed of social policy experts and decision-makers puzzling over the discursive and practical foundations for reforms to social policy after the failed experiments of the neoliberal

\footnotetext{
${ }^{7}$ Via a comparative analysis, Mary Daly (2011) does dispute the full application of the model, however.
} 
moment (Jenson 2010). Three key ideas form the representational ensemble of this policy perspective (Jenson and Saint-Martin 2006). First is the notion of constant learning, leading to a preoccupation with human capital, and especially with early childhood education and care. Second is an orientation to the future; children are now already creating the future according to this discourse. This is sometimes called a child-centred strategy. ${ }^{8}$ Finally, there is the idea that successful individuals enrich our common future, and ensuring individuals' success is beneficial for the community as a whole, now and into the future. Incorporation of these three principles into social policy has consequences for policy design and state action.

We can now identify two policy directions of the social investment perspective that build on these three principles. ${ }^{9}$ First, based on a diagnosis of the needs of the knowledge-based economy for trained workers and for higher employment rates in order to sustain social protection, especially pensions, the treatment applied is implementing policies and programmes that better prepare children for the future, including by breaking the intergenerational transmission of poverty. Concretely, this perspective translates into sustained attention to education as an investment in human capital. ${ }^{10}$ In this way, the hope initially expressed via a book dedication has become a policy principle, most recently expressed in the EU's 2013 Social Investment Package: "Focusing on children is vital for a sustainable, efficient, and competitive knowledge economy and an intergenerational fair society. The adequacy of future pensions depends on the human capital of those who are today children" (European Commission 2013a, 13). ${ }^{11}$

Second, because of the importance of the idea that parental employment is the way to break the intergenerational cycle of poverty, the second policy direction is to raise employment levels. From a social investment perspective, children do better when parents are employed, and therefore some public support may be necessary to allow them to move into the labour market. This was the mantra of post-1997 New Labour, whose main idea about how to end child poverty was to combat "worklessness" by moving parents into employment, with various employment supports as well as income supplements made available to them to "make work pay," and childcare credits and services (Dobrowolsky and Jenson 2005). It continues through the EU's attention to avoiding "inactivity traps" into which parents may fall, as well as to increase labour force participation of

\footnotetext{
${ }^{8}$ Esping-Andersen et al. (2002, chapter 2) use this expression, and it is now widely deployed. For example, a manifesto for a social investment pact binding European countries, published by influential think tank Observatoire social européen (OSE), says: "Access to affordable quality childcare is a sine qua non [of] any workable future equilibrium. The emphasis on early-childhood education and development goes beyond the idea that childcare is necessary to allow mothers and fathers to reconcile work and family life. A 'child-centred social investment strategy' is needed to ensure that children become lifelong learners and strong contributors to their societies" (Vandenbroucke, Hemerijck, and Palier 2011, 22).

${ }^{9}$ This characterisation of the social investment perspective draws on, among others, Jenson $(2010 ; 2012)$.

${ }^{10}$ The EU uses effective public education as the example of where social policy should be moving: "Modernising social policies is a matter of common concern at [the] EU level, as ineffective social policies in one country can have consequences for others, particularly within the Eurozone. Insufficient investment in social policies that strengthen human capital development, for instance in early childhood education and care, is manifested in lower educational levels and overall lower skill development in some Member States." This is from the lead paragraph in section 2, "What is needed," of the Social Investment Package (European Commission 2013a, 8).

${ }^{11}$ The dedication is: "For today's children who will provide for our welfare when we are old. It is for you - and hence for ourselves - that we desire the best possible welfare state" (Esping-Andersen et al. 2002, v). This analysis has been codified as the postulate that "good pension policies - like good health policies - begin at birth" (Vandenbroucke, Hemerijck, and Palier 2011, 6).
} 
lone parents. Thus, for the EU, early childhood education and care has a double mission of preparing the future labour force and promoting women's employment. This can be said equally about numerous national understandings of early childhood education services (Morel, Palier, and Palme 2012, 154-55).

The social investment perspective's macro-economic analysis retains the focus on the supply-side that neoliberalism instituted, and it is in this context that talk of social investment (rather than spending) provides discursive coherence. When enthusiastic about the market, it is of course natural to use a discourse of investing. Individuals and their families are called upon "to invest in their own human capital" so as to succeed in the labour market. At the same time, they must invest in their own futures, via savings for their retirement pensions and their children's education. But, in contrast to neoliberal ideas, the state is also meant to share some of this responsibility, by ensuring adequate services (for example, childcare) as well as by income transfers to make up for the fact that market incomes are often not high enough to meet family needs.

Nor is the perspective simply an anti-poverty measure; social investments are for the middle class, too. It is an understanding of public interventions, in other words, that rallies those who want social policy to focus on education (including early childhood education), on training, and on making work pay, as well as those who are concerned about child poverty. Sharing the OECD's discourse that emerged in the mid-1990s that social spending is not a burden but an investment in economic growth, the European Union could move towards its own version, describing social policy as a productive factor in the late 1990s (Morel, Palier, and Palme 2012, 11; Chapter 2).

It took time for national and supranational policy processes to generate consensus about the social investment perspective that now exists (Kvist 2013; Cantillon and Van Lancker 2013). Indeed, it was only in 2013 that the EU finally brought forth its Social Investment Package, after vacillating for more than a decade between a focus on poverty and social inclusion (Daly 2006) and one on "social investments," particularly in children (Jenson 2008). Some national governments moved more decisively, however, both deploying a discourse of social investments and adopting its programmes since the mid-1990s (Jenson and Saint-Martin 2006; Morel, Palier, and Palme 2012, 46). This perspective has most often been used to frame contemporary European policy interventions in Nordic or liberal welfare regimes (Kvist 2013, 92). Bismarckian regimes have been slower, however, to move towards social investment (Morel, Palier, and Palme 2012, 82).

This ends the general characterisation of the social investment perspective. It is now time to describe the ways in which a process of reinscribing maternalism underpins its development and the two mechanisms that drive this process.

\section{Maternalism in the social investment perspective}

The reinscription of maternalism in the social policy perspective and the universe of political discourse more broadly is a process that operates via two key social mechanisms. One can be labelled "being gender aware," and a second is "writing out gender equality." With respect to the second, issues of gender equality are simply left aside, even while gender awareness allows analysts to identify gender inequalities. Writing out equality goals is sometimes very difficult to see precisely because there is, in the social investment discourse, so much "talk" about gender 
inequality following from gender awareness of women's structured disadvantages. However, careful attention to the universe of political discourse can show how it works.

\section{Being gender aware}

The social investment perspective is profoundly gender aware, and sensitivity to gender differences drives its implementation. As the official European definition puts it: "Gender awareness is an understanding that there are socially determined differences between women and men based on learned behavior, which affect their ability to access and control resources. This awareness needs to be applied through gender analysis into programmes, policies and evaluation." ${ }^{12}$ In the EU, promoting gender awareness is an integral part of the mainstreaming initiative. ${ }^{13}$ Practices of gender awareness identify "understanding" as the objective; elimination of inequalities is not a goal. Once sensitive to gender differences, policy can work around them to achieve its primary goals such as activation or social inclusion in ways that never ignore gender differences, but do not seek to eliminate them, either.

Currently, the social investment perspective deployed at both national and Union level is very gender aware, with significant discursive and analytic attention going to women's situations, particularly with respect to new social risks. However, arguments tend towards an instrumentalisation of women, with most attention going to the social contribution of women's willingness to bear children and reconcile motherhood with employment.

Explicit gender awareness developed in conjunction with and as a driver of the systematisation of ideas about social investment. In a 1997 foundational analysis, OECD policy analysts presented all the elements of an embryonic social investment - explicitly named as such - approach to reforming social protection. ${ }^{14}$ This report of a high-level conference seeking to identify the social policy agenda for the new millennium listed the advantages of a "social investment approach" over piecemeal reforms. A good package would include early interventions (including the transition to school, that is, early education and care), support for employment activation rather than "passive" benefits, and support for carers (OECD 1997, 18-19). In particular, the demographic challenge of low fertility as well as postponed or precocious fertility and "family stability" received significant attention (ibid., 10). Women were barely mentioned by name. The exception was the section on fertility. Thus, when women were spotlighted, only their maternal roles received attention.

The mechanism of being gender aware was clearly important, however, in the next foundational document of the social investment perspective, and it grounded a discourse of maternalism. An

\footnotetext{
${ }^{12}$ From the glossary provided by the Equality Unit: http://ec.europa.eu/justice/gender-equality/glossary/index_en.htm Accessed 24 November 2014. The concept of "gender awareness" is also widespread in literature on the Global South (Molyneux 2006).

${ }^{13}$ See, for example, the European Institute for Gender Equality (EIGE): http://eige.europa.eu/sites/default/files/Good-Practices-in-Gender-Mainstreaming-towards-effective-gendertraining_0.pdf, accessed 24 November 2014. The publication overviews national-level good practices for training and for raising public and decision-makers' awareness of gender differences.

${ }^{14}$ The article developed the analysis of social and demographic change leading to weaknesses in existing social protection systems. Because, as the saying goes, a picture is always worth a thousand words, the OECD Observer illustrated this important article with three photos: Gustav Möller and Lord Beveridge, "founders of the modern welfare state," and a very young woman with two pre-school-age children, with the caption strongly suggesting she was a lone parent (Pearson and Scherer 1997, 7, 9).
} 
important report prepared for the Belgian presidency of the European Council in 2000 claimed "there is clearly a strong case for a new 'women-friendly' social contract because improving the welfare of women means improving the collective welfare of society at large" (Esping-Andersen et al. 2002, 20). ${ }^{15}$ Being gender aware brought two prescriptions: solving the "compatibility problem" of women pursuing both careers and motherhood, and promoting gender equality by making men's lives more like women's. With the identification of the "compatibility problem," we clearly see the use of an instrumentalist maternalist discourse; women's social contribution is made via their fertility and child-raising. Women-friendly family policies (leaves and childcare) are needed because women "place a strong priority on forming families" (ibid., 70). But only the first prescription was viable; the second solution was dismissed as unlikely (ibid., 95).

This mechanism of being gender aware provides much of the coherence of the social investment perspective. Another example from the 2011 publication of an important think-tank illustrates this. The Observatoire social européen explained why Europe (both the EU and Member States) "needs a social investment pact" (Vandenbroucke, Hemerijck, and Palier 2011). Being aware of gender differences in both employment opportunities and family responsibilities - women have less access to employment and more family responsibilities - the publication proposed reducing the negative effects of this difference in a social investment pact that would include improved labour law and protections for part-time work. In other words, maternity was beginning to trump fulltime employment within the social investment perspective. Such an emphasis on acknowledging and protecting a part-time employment track for mothers with children was not at all inimical to pursuing a social investment strategy, of course. Often singled out as the initiator of the perspective (Morel, Palier, and Palme 2012, 2, 17), Sweden has traditionally had a high rate of female parttime employment.

The mechanism of being gender aware similarly structured the discussion in the European Union's social investment package in 2013. The "continued gender disadvantage" merited its own section, and Member States were urged to target the gender pay gap and discrimination in employment (European Commission 2013a, 7, 11). The package was built on a Staff Working Document that demonstrated solid awareness of gender disadvantage, identifying an "ageing population" due to low fertility as the first worrisome long-term trend that social investments would need to address. Women were described as more vulnerable to poverty because of their responsibilities for caring for children, and also as reducing their child-bearing rates (European Commission 2013b, 7-8, 25). Having a gender-aware discourse supported the familiar reinscription of maternalism into the social investment perspective.

Despite the fact that the Commission and its staff were clearly deploying the mechanism of being gender aware, another noticeable and important pattern emerged in these documents. Attention to children, the intergenerational cycle of disadvantage and the need for investing in human capital far outweighed any attention going to gender inequalities between adults. This pattern mimicked closely that described by Molyneux $(2006,438)$, as Mexico used gender awareness to move toward the social investment perspective: "The new anti-poverty programmes may successfully identify some unmet needs within poor households and communities, but attending to the diverse needs of the women (the mothers) who are central to the functioning of these programmes is not their

\footnotetext{
${ }^{15}$ This citation is from the more-readily accessible book that is a revised version of the 2000 report to the Belgian presidency. The same sentence appeared in that report on p. 9.
} 
explicit aim, any more than is gender equality a consistently observed objective. The social construction of need in these programmes is child-centred, as is their overall organization." In other words, being gender aware was reinforcing maternalism and actually closing down space for promotion of gender equality. A second mechanism was the operative driver here.

\section{Writing out gender equality}

The second mechanism in the process of inscribing maternalism into the social investment perspective is that of writing out gender equality. This mechanism has been in play for well over a decade. In both national situations and the EU, there is an on-going tendency to talk gender equality, but to devote much less action than previously to strategies for promoting and achieving it. There has been a shift towards focusing on violence against women and the guarantee of sexual rights; they now preoccupy the institutional machinery originally designed to advance gender equality (Jacquot 2014; Jenson 2008). The result is that promoters of the social investment, all the while exhibiting awareness of gender inequalities, have ample space to actually do very little to promote equality.

As an initiator of the social investment perspective, the OECD was also a leader in writing out gender equality for adult women from the universe of political discourse. This happened in two ways. The first was indirect, as women were relabelled with the gender-neutral term "parent" or "worker." Both terms were used in discourse advocating for "family-friendly" social policies. In its Babies and Bosses series, for example, the OECD's analysis of the work-family balance nexus was originally driven by several concerns: declining fertility, poverty, and gender pay gaps. ${ }^{16}$ By the time of the synthesis report in 2007, however, the analysis had been pared down to demographic and labour supply questions, framed in a classic social investment discourse as concern with employment for all and the future of society. Equality was invisible and maternalism a concern:

If parents cannot achieve their desired work/family life balance, not only is their welfare lower, but economic development is also curtailed through reduced labour supply by parents. A reduction of birth rates has obvious implications for future labour supply as well as for the financial sustainability of social protection systems. As parenting is also crucial to child development, and thus the shape of future societies, policy makers have many reasons to want to help parents find a better work/family balance. ${ }^{17}$

Even more striking was reliance by the OECD on the mechanism of directly writing out gender equality even while the Organisation manifested new gender sensitivity. A careful analysis of the path-breaking Closing the Gender Gap. Act Now reveals a pirouette-like flourish of writing out gender equality even while reporting massive amounts of data about inequalities between women and men. The three domains in which equality might be achieved, according to the OECD, are education, employment, and entrepreneurship. In the first case, there are quite specific policy proposals for "greater gender equality in educational attainment." The target is girls. The expectation for adult women, however, is only "improved female labour market outcomes"

16 See the 2004 presentation of the three-country study (New Zealand, Portugal, and Switzerland) at http://www.oecd.org/els/family/babiesandbosses-

reconcilingworkandfamilylifevol3newzealandportugalswitzerland.htm, accessed 24 November 2014.

${ }^{17}$ This quote is from the presentation of the synthesis report on http://www.oecd.org/els/family/babies andbossesreconcilingworkandfamilylifeasynthesisoffindingsforoecdcountries.htm, accessed 24 November 2014. 
(OECD 2012, 18). Despite the excellent diagnosis of gender disadvantages, in other words, when policy recommendations for adult women are proposed, equality is no longer explicitly the goal. The discussion turns almost exclusively on the hindrances - usually of values within the home or the workplace - that have generated the acknowledged inequalities. There are few strong policy prescriptions laid out. Rather, employers should try harder because it is their own interest to do so and governments should remove disincentives to employment.

This lack of a strategic push for gender equality by the promoters of social investment prescriptions sometimes comes with a strong dose of pessimism about achieving equality. As the foundational document quoted above put it, ultimately "true gender equality will not come about unless, somehow, men can be made to embrace a more feminine life course. Whether or not such a scenario would truly conform to the prevailing choice set of today's men and women is pretty unclear" (Esping-Andersen et al. 2002, 95). ${ }^{18}$ The policy conclusion is that motherhood requires support because equal parenting seems unlikely.

In discussing women's careers and maternity, in a later analysis than that presented above, EspingAndersen does not even gesture in the direction of one of the most important equality claims equal pay. In his detailed calculations meant to convince economists and policy-makers of the payoffs from investments in non-parental childcare, he simply accepts the standard that women's wages will be $67 \%$ of men's $(2009,96)$. In his analysis, the most important policy instrument available to achieve an appropriate work-family balance is non-parental child care. ${ }^{19}$ The defamilialisation of care for pre-school children will, according to the policy prescriptions, allow women successfully to combine employment and motherhood, and thereby avoid the demographic crisis facing Europe. There is, as the calculation of the wage gap demonstrates, no attention to the actual quality of the job, in terms of the adequacy of earnings or career potential. Equality between women and men is lost in the calculation.

The mechanism of writing out was also clearly observable in the discourse of the EU as it moved towards the social investment perspective. For the past 40 years, the EU has consistently affirmed and reaffirmed that gender equality is a fundamental value. There has nonetheless also been a systematic weakening of the policy instruments that might achieve this equality. ${ }^{20}$ Studies have tracked the steady erasing of gender equality goals from the European Employment Strategy (Fagen, Grimshaw, and Rubery 2006; Jenson 2008, 10; Jacquot 2014, ch. 5). The Employment Guidelines were integrated with those of growth and jobs in the mid-2000s, and there were, for the first time, no targets for gender equality. There were, of course, targets for women's employment rates and even services to support their achievement, but the notion of "good" or "better" jobs as a route to gender equality had disappeared. This writing-out of gender equality continued. Villa and Smith (2013) report that in the first draft of Europe 2020 it was not mentioned; queries from

\footnotetext{
18 The pessimism is unabated and more elaborated in later work (Esping-Andersen 2009, 102).

${ }^{19}$ As the books make clear, public spending is necessary because there is little chance of any real feminisation of masculine roles. The only route to completing the revolution is for the state to support masculinisation of women's life roles. See this most clearly in the conclusion to Esping-Andersen (2009).

${ }^{20}$ For example, Stratigaki (2004) and Jacquot (2014, ch. 3) describe how proponents of gender mainstreaming as a policy tool to replace interventions to promote equality prevailed in political competition within the European Commission.
} 
some "mystified" Member States brought the words back, but the commitment was minimal (Jacquot 2014, 303ff).

This writing-out of gender equality in economic strategy is made easier by a second modification of the EU's approach to gender equality. The Commission's interventions on gender, via its gender administrative machinery, have moved from promotion to rhetorical enthusiasm, and this despite institutionalisation, including of mainstreaming (Jacquot 2010, 2014). For example, between 1982 and 2006, the Commission elaborated five action programmes for equal opportunities between women and men. As they developed through the years, they broadened the analysis of the structure underpinning gender inequalities. At first, they also deployed tools to overcome them, within the double perspective of equal treatment and equal opportunities. The first perspective led most often to using the power of legislation and the second to positive action via specific and targeted programmes. ${ }^{21}$ However, by the decade of the Lisbon Strategy, with its emphasis on policy coordination rather than legislation, the Framework Strategy for equality between women and men (2001-05) and the Roadmap for equality between women and men (2006-10) began to set out principles and call for Member State action that did not mention policy instruments for action. The link to financing that shaped earlier programmes was also broken. No incentives were proposed. Only the rhetorical commitment of the supranational institutions remained (Jacquot 2014, 302, ch. 5).

\section{Conclusion}

The two mechanisms of writing out gender equality and being gender aware worked together to reinscribe maternalism into the social investment perspective, now described as dominant in social policy across Europe and at the European level. The presence of both was needed to give coherence to a social investment perspective that focused on women as mothers. Being gender aware and sensitive to differences in care practices both traditionally and into the present, it was easy to arrive at an instrumentalisation of women's lives as primarily ones of child-bearing and raising. This maternal nexus in the universe of political discourse marked a return to a discourse present in the first five decades of the $20^{\text {th }}$ century: the acceptance of distinct gender roles, with women primarily responsible for children. Nonetheless, and in contrast with those years when the norm of the male breadwinner held sway, in recent decades women are also expected to be employed. Given the weight of the maternalist discourse, however, it is difficult to promote forms of employment that will be fully equal. Thus, writing out gender equality is a second very important mechanism to allow maternalism to achieve coherence. Only if women have a lesser engagement with employment, for example, as part-time workers or in jobs with truncated career ladders, will it be possible for the social investment perspective to count on them to oversee familial investments in human capital and to manoeuvre and manage the complex world of childcare services at the core of the child-centred perspective.

\footnotetext{
${ }^{21}$ Jacquot (2010) summarises these two approaches before describing the new instrument - gender mainstreaming added in the 1990s as the EU moved towards a strategy of policy coordination rather than relying on the Community Method.
} 


\section{REFERENCES}

Ancelovici, Marcos and Jane Jenson. 2013. "Standardization for Transnational Diffusion: The Case of Truth Commissions and Conditional Cash Transfers." International Political Sociology, 7: 3, 294-312.

Bonoli, Giuliano and David Natali (eds). 2012. The Politics of the New Welfare State. Oxford: Oxford University Press.

Cantillon, Bea and Wim Van Lancker. 2013. "Three Shortcomings of the Social Investment Perspective." Social Policy \& Society, 12: 4, 553-64

Daly, Mary. 2006. "EU Social Policy after Lisbon.” Journal of Common Market Studies, 44: 3, 61-81.

—. 2011. "What Adult Worker Model? A Critical Look at Recent Social Policy Reform in Europe from a Gender and Family Perspective." Social Politics. International Studies in Gender, State and Society, 18: 1, 1-23.

Daune-Richard, Anne-Marie and Rianne Mahon. 2001. "Sweden: Models in Crisis". In Jane Jenson and Mariette Sineau (eds.), Who Cares? Women's Work, Childcare, and Welfare State Redesign. Toronto: University of Toronto Press, 146-76.

Dobrowolsky, Alexandra and Jane Jenson. 2005. "Social investment perspectives and practices: a decade in British politics". Social Policy Review, \#17, 203-30.

Esping-Andersen, Gøsta. 2009. The Incomplete Revolution: Adapting to Women's New Roles. Cambridge, UK: Polity.

Esping-Andersen, Gøsta, Duncan Gallie, Anton Hemerijck, and John Myles. 2002. Why we need a new welfare state. Oxford: Oxford University Press.

European Commission. 2013a. Towards Social Investment for Growth and Cohesion - including implementing the European Social Fund 2014-2020. COM (2013) 83 final.

- 2013b. Evidence on Demographic and Social Trends. Social Policies' Contribution to Inclusion, Employment and the Economy, Staff Working Document, SWD (2013) 38 final.

Evers, Adalbert and Anne-Marie Guillemard (eds). 2012. Social Policy and Citizenship. The Changing Landscape. Oxford: Oxford University Press.

Fagen, Colette, Damian Grimshaw and Jill Rubery. 2006. "The subordination of the gender equality objective: the National Reform Programmes and 'making work pay' policies." Industrial Relations Journal, 37: 6, 571-92. 
Gottschall, Karin and Katherine Bird. 2003. "Family Leave Policies and Labor Market Segregation in Germany. Reinvention or Reform of the Male Breadwinner Model." Review of Policy Research, 20: 1, 115-34.

Hall, Peter. 1993. "Policy Paradigms, Social Learning, and the State: The Case of Economic Policymaking in Britain.” Comparative Politics, 25: 3, 275-96.

Heclo, Hugh. 1974. Modern Social Policy in Britain and Sweden. From Relief to Income Maintenance. Essex, UK: ECPR Press.

Hemerijck, Anton. 2013. Changing Welfare States. Oxford: Oxford University Press.

Jacquot, Sophie. 2010. "The Paradox of Gender Mainstreaming: Unanticipated Effects of New Modes of Governance in the Gender Equality Domain.” West European Politics, 33: 1, 118-35.

- 2014. L'égalité au nom du marché ? Émergence et démantèlement de la politique européenne d'égalité entre les hommes et les femmes. Bruxelles: P.I.E. Peter Lang.

Jenson, Jane. 1989. "Paradigms and Political Discourse: Protective Legislation in France and the United States Before 1914.” Canadian Journal of Political Science, XXII: 2, June, 23558.

- 2008. "Writing Women Out, Folding Gender In. The European Union 'Modernises' Social Policy.” Social Politics. International Studies in Gender, State and Society, 15: 2, $1-23$.

- 2010. "Diffusing ideas for after-neoliberalism: The social investment perspective in Europe and Latin America." Global Social Politics, vol. 10: 1, 59-84.

- 2012. "Redesigning citizenship regimes after neoliberalism. Moving towards social investment." In Nathalie Morel, Bruno Palier \& Joakim Palme, Towards a social investment welfare state? Ideas, policies and challenges, Bristol: Policy Press, 61-90.

Jenson, Jane and Denis Saint-Martin. 2006. "Building blocks for a new social architecture: the LEGO $^{\mathrm{TM}}$ paradigm of an active society.” Policy \& Politics, 34: 3, 429-51.

Klas, Urban and Klas Ámark. 2001. "Social Rights and Social Security: The Swedish Welfare State, 1900-2010.” Scandinavian Journal of History, 26: 3, 157-76.

Koven, Seth and Sonya Michel (eds). 1990. "Womanly Duties: Maternalist Politics and the Origins of Welfare States in France, Germany, Great Britain, and the United States, 1880-1920." The American Historical Review, 95: 4, 1076-1108. 
Kvist, Jon. 2013. "The post-crisis European social model: developing or dismantling social investments?” Journal of International and Comparative Social Policy, 29:1, 91-107.

Lewis, Jane. 2001. "The Decline of the Male Breadwinner Model: Implications for Work and Care." Social Politics. International Studies in Gender, State and Society, 8: 2, 152-69.

Lewis, Jane, Trudie Knijn, Claude Martin and Ilona Ostner. 2008. "Patterns of Development in Work/Family Reconciliation Policies for Parents in France, Germany, the Netherlands, and the UK in the 2000s." Social Politics. International Studies in Gender, State and Society, 15: $3,261-86$.

Mahon, Rianne. 2006. "The OECD and the work-family reconciliation agenda. Competing frames." In Jane Lewis (ed.), Children, Changing Families and Welfare States. Cheltenham: Edward Elgar.

Molyneux, Maxine. 2006. "Mothers at the Service of the New Poverty Agenda: Progresa/Oportunidades, Mexico's Conditional Transfer Programme." Social Politics \& Administration, vol. 40: 4, 429-40.

Morel, Nathalie, Bruno Palier and Joakim Palme (eds). 2012. Towards a social investment state? Ideas, policies and challenges. Bristol: The Policy Press.

OECD [Organisation of Economic Cooperation and Development]. 1997. Beyond 2000: The New Social Policy Agenda. OECD Working Paper, vol. V, \#43, Paris: OECD.

. 2011. Divided We Stand. Paris: OECD.

- 2012. Closing the Gender Gap. Act Now. Paris: OECD.

Offen, Karen. 1988. “Defining Feminism: A Comparative Historical Approach.” Signs, 14: 1, 11957.

Padamsee, Tasleem J. 2009. "Culture in Connection: Re-Contextualizing Ideational Processes in the Analysis of Policy Development." Social Politics. 16: 4, 413-45.

Paquet, Mireille. 2014. "The Federalization of Immigration and Integration in Canada." Canadian Journal of Political Science, 47: 3, 519-48.

Pearson, Mark and Peter Scherer. 1997. "Balancing Security.” OECD Observer, \#205, April-May, 6-9.

Smith, Miriam. 2007. "Framing Sam-Sex Marriage in Canada and the United States: Goodridge, Halpern and the National Boundaries of Political Discourse." Social and Legal Studies, 16: $1,5-26$. 
Stratigaki, Maria. 2004. "The Cooptation of Gender Concepts in EU Policies: The Case of 'Reconciliation of Work and Family"'. Social Politics. International Studies in Gender, State and Society, vol. 11: 1, 30-56.

Vandenbroucke, Frank, Anton Hemerijck, and Bruno Palier. 2011. The EU needs a Social Investment Pact. Observatoire social européen, Opinion Paper \#5. Brussels: OSE.

Villa, Paola and Mark Smith. 2013. "Policy in the time of crisis. Employment and Gender Policy in Europe." In Maria Karamessini and Jill Rubery (eds), Women and Austerity. The Economic Crisis and the Future for Gender Equality. Milton Park: Routledge, 273-94. 
Published by the Centre for European Studies at Carleton University, Ottawa, Canada Available online at: journals.carleton.ca/rera/index.php/rera

RERA is an electronic academic peer-reviewed journal that publishes graduate, post-graduate, and young scholarly works. Topics relate to the European Union, its Member States, the former Soviet Union, and Central and Eastern Europe. The journal is a joint project supported by the CanadaEurope Transatlantic Dialogue - a cross-Canada research network supported by the Social Sciences and Humanities Research Council of Canada (SSHRC) - along with the Institute of European, Russian and Eurasian Studies (Carleton University) and its associated research unit, the Centre for European Studies.

RERA aims to provide an accessible forum for research, to promote high standards of research and scholarship, and to foster communication among young scholars.

\section{Contact:}

Carleton University

The Centre for European Studies

1103 Dunton Tower

1125 Colonel By Drive

Ottawa, ON K1S 5B6

Canada

Tel: +01 613 520-2600 ext. 3117; E-mail: rera-journal@ carleton.ca

\section{Creative Commons License}

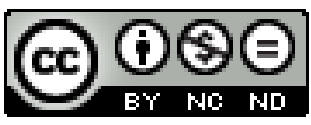

creativecommons.org/licenses/by-nc-nd/3.0

This Working Paper is licensed under a Creative Commons Attribution-Non-CommercialNo Derivs 3.0 Unported License (CC BY-NC-ND 3.0).

Articles appearing in this publication may be freely quoted and reproduced, provided the source is acknowledged. No use of this publication may be made for resale or other commercial purposes.

ISSN: 1718-4835

(C) 2015 The Author 